\title{
STUDI KRITIS PEMIKIRAN PEMIKIR ISLAM KONTEMPORER
}

\author{
Oleh: Hasri \\ Fakultas Tarbiyah dan IImu Keguruan IAIN Palopo
}

\begin{abstract}
Abstrak:
Perkembangan pemikiran Islam kontemporer yang luar biasa saat ini, sesungguhnya, dapat diklasifikasikan dalam 5 model kecenderungan. Pertama, fundamentalis yaitu model pemikiran yang sepenuhnya percaya pada doktrin Islam sebagai satu-satunya alternatif bagi kebangkitan Islam dan manusia. Kedua, tradisionalis (salaf) yaitu model pemikiran yang berusaha berpegang pada tradisitradisi yang telah mapan. Bagi mereka, segala persoalan umat telah diselesaikan secara tuntas oleh para ulama terdahulu. Ketiga, reformis yaitu model pemikiran yang berusaha merekonstruksi ulang warisan budaya Islam dengan cara memberi tafsiran baru. Menurut mereka, Islam telah mempunyai tradisi yang bagus dan mapan. Keempat, postradisionalis yaitu model pemikiran yang berusaha mendekonstruksi warisa Islam berdasarkan standar modern. Kelima, moderinis yaitu model pemikiran yang hanya mengakui sifat rasional-ilmiah dan menolak kecenderungan mistik. Menurutnya, tradisi masa lalu sudah tidak relevan, sehingga harus ditinggalkan. Karakter utama gerakannya adalah keharusan berpikir kritis dalam soal keagamaan dan kemasyarakatan. Mereka ini biasanya banyak dipengaruhi cara pandang marxisme. Meski demikian, mereka bukan sekuler.
\end{abstract}

\section{Kata Kunci: Pemikiran, Pemikir, Islam, Kontemporer}

\section{A. PENDAHULUAN}

\section{Latar Belakang Masalah}

Kemenangan gerakan demokratisasi di Eropa Timur dan terpecahnya Uni Soviet menjadi negara-ncgara kecil, secara tidak langsung menjadikan Islam sebagai salah satu kekuatan transnasional dengan satu milyar lebih pemeluk yang memenuhi hamper seluruh penjuru dunia. Eksistensi Islam sebagai agama dunia dan kekuatan ideologis yang dianut oleh seperlima penduduk dunia dengan vitalitas serta kekuasaannya yang terus berkembang dari Afrika sampai ke Asia Tenggara, telah menimbulkan perasaan takut dikalangan masyarakat Barat, yang menurut istilah Esposito sebagai "ancaman".

Dalam melakukan telaah terhadap pemikiran Islam, pertama-tama harus dilihat kembali pada masa para sahabat. Dari sana terlihat bahwa Sahabat Nabi Muhammad 
SAW. Yang paling kreatif dalam berfikir adalah tokoh yang kemudian menjadi khalifah kedua yakni Umar bin Al-khattab (856-644). Kraetifitas pemikiran Umar memberikan kesan kuat, sekalipun beriman teguh, ia tidak bersikap dogmatif. Umar adalah seorang beriman sekaligus intelektual, yang dengan intelektualitasnya itu ia menjadi orang yang berani mengemukakan ide-ide dan melaksanakan berbagai tindakan inovatif yang sebelumnya tidak dicontohkan nabi. Bahkan kadang-kadang ide dan tindakan itu secara sepintas lalu tampak tidak sejalan, kalau tidak malah bertentangan dengan pengertian harfiyah alKitab dan al-Sunnah.

Setelah khalifah keempat (Ali), yang juga seorang intelektual muncul sejumlah aliran dengan episteme dan wacana sendiri-sendiri. Misalnya timbul aliran Ahl al-Sunnah wa al-jamaah (golongan Sunni), yang menjadi panutan mayoritas umat. Kelompok ini behadapan dengan Khawarij yang secara teologis berpandangan bahwa seorang Muslim yang berdosa besar adalah kafir. Selain dari pada itu, jiga muncul kaum Syi'ah dan Murji'ah. Golongan Murji'ah berpendapat bahwa penuilaian terhapat seorang Muslim pendosa besar - apakah ia masih Muslim atau telah menjadi kafir, harus ditunda sampai hari kemudian dan urusannya diserahkan kepada Allah SWT. Disamping itu, ada paham jabariah, faham keterpaksaan manusia dihadapan Tuhan.

Dalam beberapa tulisannya, Arkoun tidak secara tegas merumuskan batasan modernitas, apalagi tantangan yang dibawa olehnya. Meskipun demikian, pandangan Arkoun tentang persoalan modernitas ini dapat disimak dari pelbagai tulisannya. Namun demikian tidak dapat dipungkiri bahwa terdapat mata rantai yang tidak terputus atau boleh dikatakan kelanjutan antara modernitas dengan kemajuan di masa lalu. Terlepas dari kapan modernitas itu lahir, yang perlu digaris bawahi adalahpenyebutan tahap perkembangan sejarah manusia yang berlangsung sekarang ini sebagai zaman modern bukannya tanpa masalah.

Di sisi lain, muncul golongan Mu'tazilah yang beraliran rasionalis yang memandang akal mempunyai kedudukan yang sama dengan wahyu dalam memahami Agama. Selanjutnya golongan Mu'tazilah menjadi perintis bagi tumbuhnya disiplin baru dalam kajian Islam (ilmu al-kalam) khususnya dalam bentuk pemikiran apologetic menghadap agama-agama lain dengan lawan mereka sendiri di kalangan umat Islam. 
Dalam perkembangannya kaum Mu'tazilah menjadi sangat dekat dengan kaum yang berpendapat bahwa manusia sepenuhnya mempunyai kemampuan memilih dan menentukan tindakannya sendiri, baik atau buruk.

Dalam perkembangan selanjutnya, yaitu pada awal-awal abad ke-20, pemikiran-pemikiran tentang kebangkitan umat Islam semakin mencuat ke permukaan. Pemikiran tersebut pada intinya merupakan upaya dan perjuangan menegakkan citacita Islam sebagaimana diakselerasikan pada akhir abad ke 20 ini yang secara normative akan dapat memberikan suatu kepastian hidup di masa depan.

\section{Rumusan Masalah}

Adapun rumusan masalah yang akan dibahas dalam makalah ini sebagai berikut:

1. Apa hakekat pemikiran kontemporer?

2. Mengapa terjadi kecendrungan-kecendrungan dalam model pemikiran Islam kontemporer tersebut?

3. Bagaimana pengaruh perkembangan pemikiran tersebut terhadap kemajuan sosial kemasyarakatan dan keagamaan?

\section{B. PEMBAHASAN}

\section{Hakekat Pemikiran Kontemporer}

Pertama, fundamentalis yaitu model pemikiran yang sepenuhnya percaya pada doktrin Islam sebagai satu-satunya alternatif bagi kebangkitan Islam dan manusia. Mereka biasanya dikenal sangat commited pada aspek religius budaya Islam. Bagi mereka, Islam telah mencakup segala aspek kehidupan sehingga tidak memerlukan segala teori dan metode dari luar, apalagi Barat. Garapan utamanya adalah menghidupkan kembali Islam sebagai agama, budaya sekaligus peradaban, dengan menyerukan untuk kembali pada sumber asli (al-Qur'an dan Sunnah) dan mempraktekkan ajaran Islam sebagaimana yang dilakukan Rasul dan Khulafa' alRasyidin. Tradisi dan Sunnah Rasul harus dihidupkan kembali dalam kehidupan modern sebagai bentuk kebangkitan Islam.

Kedua, tradisionalis (salaf) yaitu model pemikiran yang berusaha berpegang pada tradisi-tradisi yang telah mapan. Bagi mereka, segala persoalan umat telah diselesaikan secara tuntas oleh para ulama terdahulu. Tugas kita sekarang hanyalah 
menyatakan kembali atau merujukkan dengannya. Perbedaan kelompok ini dengan fundamentalis terletak pada penerimaannya pada tradisi. Fundamentalis membatasi tradisi yang diterima hanya sampai pada khulafa' al-rasyidin, sedang tradisionalis melebarkan sampai pada salaf al-shalih , sehingga mereka bisa menerima kitab-kitab klasik sebagai bahan rujukannya. Hasan Hanafi pernah mengkritik model pemikiran ini. Yaitu, bahwa tradisionalis akan menggiring pada ekslusifisme, subjektivisme dan diterminisme.

Ketiga, reformis yaitu model pemikiran yang berusaha merekonstruksi ulang warisan budaya Islam dengan cara memberi tafsiran baru. Menurut mereka, Islam telah mempunyai tradisi yang bagus dan mapan. Akan tetapi, tradisi ini tidak dapat langsung diaplikasikan melainkan harus harus dibangun kembali secara baru dengan kerangka berpikir modern dan prasyarat rasional, sehingga bisa survive dan diterima dalam kehidupan modern. Karena itu, mereka berbeda dengan tradisionalis yang menjaga dan menerima tradisi seperti apa adanya.

Keempat, postradisionalis yaitu model pemikiran yang berusaha mendekonstruksi warisa Islam berdasarkan standar modern. Model ini sesungguhnya sama dengan reformis yang menerima tradisi dengan interpertasi baru. Perbedaannya, postadisionalis mempersyaratkan dekonstruktif atas tradisi, bukan sekedar rekonstruktif, sehingga yang absolut menjadi relatif dan yang ahistoris menjadi historis.

Kelima, moderinis yaitu model pemikiran yang hanya mengakui sifat rasionalilmiah dan menolak kecenderungan mistik. Menurutnya, tradisi masa lalu sudah tidak relevan, sehingga harus ditinggalkan. Karakter utama gerakannya adalah keharusan berpikir kritis dalam soal keagamaan dan kemasyarakatan. Mereka ini biasanya banyak dipengaruhi cara pandang marxisme. Meski demikian, mereka bukan sekuler. Sebaliknya, mereka bahkan mengkritik sekuler selain salaf. Menurutnya, kaum sekuler telah bersalah karena berlaku eklektif terhadap Barat, sedang kaum salaf bersalah menempatkan tradisi klasik pada posisi sakral dan shalih likulli zaman wa makan . Sebab, kenyataannya, tradisi sekarang berbeda dengan masa lalu. Modernis menjadikan orang lain (Barat) sebagai model, sedang salaf menjadikan masa lalu sebagai model. Keduanya sama-sama ahistoris dan tidak kreatif, sehingga tidak akan mampu membangun peradaban Islam ke depan. 


\section{Kecendrungan-kecendrungan dalam Model Pemikiran Islam Kontemporer}

Kecenderungan-kecendrungan dalam model pemikiran Islam kontemporer antara lain:

a) Fundamentalis

Sebagai ideologi gerakan Islam kontemporer, fundamentalisme mewujudkan diri dalam beragam bentuk, dan berkaitan erat dengan orientasi ideologi lain, seperti revivalisme, Islamisme (neo-fundamentalisme) dan radikalisme. Sekalipun pada mulanya fundamentalisme lebih menunjukkan watak keagamaan, ia kemudian lebih dipahami sebagai bentuk ekspresi Islam yang berdimensi politik. Hal ini mudah dipahami karena dalam perkembangannya fundamentalisme mewujudkan diri dalam bentuk kegiatan atau gerakan politik, yang bahkan seringkali bersifat radikal atau militan, melawan rejim penguasa sekular, atau berjuang untuk membangun sistem kenegaraan yang didasarkan pada syari'ah (Islam).

Meskipun istilah fundamentalisme, revivalisme, Islamisme dan radikalisme sering digunakan secara bergantian untuk maksud penyederhanaan (simplifikasi), kebanyakan sarjana mencoba melakukan identifikasi terhadap karakteristik masingmasing gerakan atau orientasi ideologinya. Para sarjana, seperti akan disebutkan, biasanya merujuk kepada gerakan-gerakan atau pemikir-pemikir Muslim yang memiliki kaitan dan afiliasi dengan gerakan Islam kontemporer tertentu di dunia Islam, seperti kawasan Timur Tengah, Afrika Utara, Indo-Pakistan dan Asia Tenggara. Mereka menemukan adanya beberapa karakteristik umum (common characteristics) sekaligus keunikan (peculiarities) dari pelbagai gerakan "fundamentalisme" Islam.

b) Fundamentalisme Islam

Istilah fundamentalisme muncul dari luar tradisi sejarah Islam, dan pada mulanya merupakan gerakan keagamaan yang timbul di kalangan kaum Protestan di Amerika Serikat pada 1920-an. Menilik asal-usulnya ini, kita dapat mengatakan bahwa fundamentalisme sesungguhnya sangat tipikal Kristen. Namun, terlepas dari latar belakang Protestan-nya, istilah fundamentalisme sering digunakan untuk menunjuk fenomena keagamaan yang memiliki kemiripan dengan karakter dasar fundamentalisme Protestan. Karena itu, kita dapat menemukan fenomena pemikiran, gerakan dan kelompok fundamentalis di semua agama, seperti fundamentalisme Islam, 
Yahudi, Hindu, dan Budhisme. Dalam hal ini, selain fundamentalisme tidak terbatas pada agama tertentu, dalam faktanya ia juga tidak hanya muncul di kalangan kaum miskin dan tidak terdidik. Fundamentalisme dalam bentuk apapun bisa muncul di mana saja ketika orang-orang melihat adanya kebutuhan untuk melawan budaya sekular (godless), bahkan ketika mereka harus menyimpang dari ortodoksi tradisi mereka untuk melakukan perlawanan itu.

Salah satu karakteristik atau ciri terpenting dari fundamentalisme Islam ialah pendekatannya yang literal terhadap sumber Islam (al-Qur'an dan al-Sunnah). Literalisme kaum fundamentalis tampak pada ketidaksediaan mereka untuk melakukan penafsiran rasional dan intelektual, karena mereka -kalau-lah membuat penafsiransesungguhnya adalah penafsir-penafsir yang sempit dan sangat ideologis. Literalisme ini berkoinsidensi dengan semangat skripturalisme, meskipun Leonard Binder membuat kategori fundamentalisme non-skriptural untuk pemikir fundamentalis seperti Sayyid Qutb.

Olivier Roy membedakan antara fundamentalisme Islam tradisional dan modern. Fundamentalisme tradisional ('ulama) dicirikan oleh kuatnya peran ulama atau oligarki klerikal (clerical oligarchy) dalam membuat penafsiran terhadap Islam, terutama Syi'ah. Islam Syî'ah memberikan otoritas sangat besar kepada 'ulama untuk menafsirkan doktrin agama. Tafsir mereka pun bersifat absolut. Akibatnya, kebebasan intelektual untuk menafsirkan teks-teks agama menjadi sangat sempit dan terbatas. Dapat dinyatakan bahwa salah satu faktor yang mendukung berkembangnya fundamentalisme (tradisional) adalah kuatnya otoritas 'ulama, termasuk dalam hal-hal yang berkaitan dengan kehidupan sosial dan politik. Dalam hal ini, tampak adanya kemiripan antara fundamentalisme di satu pihak dan tradisionalisme di pihak lain.

Sedangkan fundamentalisme modern atau neo-fundamentalisme dicirikan oleh orientasi yang kuat kepada politik dengan menjadikan Islam sebagai ideologi. Islam tidak dipahami sebagai agama yang memuat doktrin tentang ritual, tetapi ditafsirkan sebagai ideologi yang diperhadapkan dnegan ideologi modern seperti kapitalisme, liberalisme atau sosialisme. Roy mengidentifikasi Islamisme sebagai bentuk lebih mutakhir dari neo-fundamentalisme. Fundamentalisme Islam modern tidak dipimpin oleh ulama (kecuali di Iran), tetapi oleh "intelektual sekuler" yang secara 
terbuka mengklaim sebagai pemikir religius. Mereka berpendapat bahwa karena semua pengetahuan itu bersifat ilahi dan religius; maka ahli kimia, teknik, insinyur, ekonomi, ahli hukum adalah ulama. Jadi, terdapat semacam anti-clericalism di kalangan fundamentalisme Islam modern, meskipun fundamentalisme dalam wajahnya yang lain juga dicirikan oleh adanya oligraki klerikal seperti disebut terdahulu.

c) Fundamentalisme dan Revivalisme

Yang agak problematik dalam konteks ini adalah korelasi antara fundamentalisme dan revivalisme. Penulis-penulis seperti Youssef Chouieri, R. Hrair Dekmejian dan John Obert Voll memiliki perspektif yang beragam dalam melihat fenomena fundamentalisme dan revivalisme. Chouieri menyatakan bahwa munculnya revivalisme Islam dilatarbelakangi oleh kemerosotan moral, sosial dan politik umat Islam. Menurutnya, revivalisme Islam hendak menjawab kemerosotan Islam dengan kembali kepada ajaran Islam yang murni. Contoh dari gerakan Islam revivalis adalah Wahhabiyyah yang memperoleh inspirasi dari Muhammad ibn 'Abd al-Wahhab (17031792) di Arabia, Shah Wali Allah (1703-1762) di India, Uthman Dan Fodio (1754-1817) di Nigeria, Gerakan Padri (1803-1837) di Sumatra, dan Sanusiyyah di Libya yang dinisbatkan kepada Muhammad 'Ali al-Sanusi (1787-1859). Chouieri melihat adanya kemiripan agenda yang menjadi karakteristik gerakan-gerakan revivalis Islam tersebut, yaitu: (a) kembali kepada Islam yang asli, memurnikan Islam dari tradisi lokal dan pengaruh budaya asing; (b) mendorong penalaran bebas, ijtihad, dan menolak taqlid; (c) perlunya hijrah dari wilayah yang didominasi oleh orang kafir (dar al-kufr); (d) keyakinan kepada adanya pemimpin yang adil dan seorang pembaru.

d) Neo-Fundamentalisme dan Islam Politik (Political Islam)

Mengikuti penjelasan Ayubi dan Roy di atas, fundamentalisme Islam juga sering digunakan untuk menunjuk Islam politik (political Islam). Ini tidak terlepas dari beberapa agenda fundamentalis di bidang politik. Watak politis fundamentalisme Islam termanifestasikan dalam simbol-simbol keagamaan yang mereka gunakan dalam konteks perjuangan politik atau kekuasaan, misalnya negara Islam, pemerintahan Islam dan formalisasi syari'ah dalam negara. Salah satu doktrin Islam fundamentalis dan pelbagai varian di dalamnya adalah bahwa tidak ada pemisahan agama dari politik. Olivier Roy menyebut paham ini sebagai Islamic political imagination (imajinasi 
politik Islam). Menurut Roy, fundamentalisme ini tampak pada Ikhwân al-Muslimîn di Mesir yang didirikan oleh Hasan al-Bannâ, dan Jamâ'at-i Islâmî di Indo-Pakistan yang didirikan oleh Abû al-A'lâ al-Mawdûdî. Keduanya mendefinisikan Islam sebagai sistem politik (ideologi) vis-à-vis ideologi-ideologi besar abad ke-20.

e) Tradisionalis

Ketika berbicara mengenai masyarakat Islam tradisional, yang terbayang adalah sebuah gambaran mengenai masyarakat yang terbelakang, masyarakat Islam yang kolot, masyarakat yang anti atau menolak perubahan (anti progresivitas), konservatif (staid approach), dan diliputi oleh sikap taqlid. Mereka adalah kelompok yang membaca dan belajar "kitab kuning", termasuk karya al-Ghazali dan ulama' fiqh klasik, dan tokoh-tokoh sufi pada zaman pertengahan Islam.

Secara etimologis, tradisional berarti kecenderungan untuk melakukan sesuatu yang telah dilakukan oleh pendahulu, dan memandang masa lampau sebagai otoritas dari segala bentuk yang telah mapan. Menurut Achamad Jainuri, kaum tradisionalis adalah mereka yang pada umumnya diidentikkan dengan ekspresi Islam lokal, serta kaum elit kultur tradisional yang tidak tertarik dengan perubahan dalam pemikiran serta praktik Islam.

Sementara itu, tradisionalisme adalah paham yang berdasar pada tradisi. Lawannya adalah modernisme, liberalisme, radikalisme, dan fundamentalisme. Berdasarkan pada pemahaman terhadap tradisi di atas, maka tradisionalisme adalah bentuk pemikiran atau keyakinan yang berpegang pada ikatan masa lampau dan sudah diperaktekkan oleh komunitas Agama. Di bidang pemikiran Islam, tradisionalisme adalah suatu ajaran yang berpegang pada Sunnah Nabi, yang diikuti oleh para Sahabat dan secara keyakinan telah diperaktekkan oleh komunitas Muslim.

Dalam konteks sosial-budaya, unsur-unsur yang terdapat pada Islam tradisional Indonesia meliputi adanya lembaga pesantren, peranan dan kepribadian kyai yang sangat menentukan dan kharismatik. Basis masa kaum tradisionalis semacam ini pada umumnya berada di pedesaan. Begitu lekatnya Islam tradisionalis di Indonesia dengan kalangan pedesaan, sampai-sampai dikatakan bahwa Islam tradionalis adalah Islam pedesaan. 
Islam tradisional secara religi bersifat kultural, secara intelektual sederhana, secara kultural bersifat sinkretik, dan secara politis bersifat oportunis. Meskipun untuk saat ini banyak kaum tradisionalis yang kontroversial dengan yang konservatif, akan tetapi peran warna konservatifme sangat kuat sekali di tingkat lokal.

Kaum tradisionalis sering digolongkan ke dalam organisasi sosial keagamaan terbesar bernama NU, sebuah organisasi keagamaan yang didirikan pada tahun 1926 di Surabaya, oleh beberapa ulama' pengasuh pesantren, di antaranya K.H. Hasyim Asy'ari (Tebu Ireng) dan K. Wahab Hasbullah (Tambak Beras).

f) Reformis

Rejuctionism mewakili sikap apriori absolut Muslim terhadap peradaban Barat dan segala produk budayanya. Barat diasosiasikan sebagai musuh utama yang mengancam eksistensi Islam dan umat Islam.Berikutnya respons kemalisme. Istilah ini diadaptasi dari nama Kemal Attaturk, presiden pertama negara Turki sekuler. Attaturk dianggap tokoh politik paling bertanggung jawab terhadap suksesnya proyek sekularisasi di dunia muslim.

Kemalisme menerima Barat apa adanya. Peradaban Barat dipandang sebagai solusi instan sekaligus kompatibel buat memecahkan permasalahanpermasalahan dunia Muslim.Bagi Attaturk, modernisasi dan westernisasi adalah dua istilah yang sinonim belaka. Dunia Muslim akan maju bila mengikuti Barat. Sebab, Barat adalah manifestasi dari kemajuan itu sendiri.Respons selanjutnya adalah respons reformisme. Respons ini mewakili keprihatinan mendalam sekelompok intelektual Muslim terhadap kondisi keterbelakangan yang mendera dunia Muslim pada umumnya.

Corak utama dari respons reformisme ini adalah sikap kooperatifnya terhadap produk-produk budaya Barat. Kendati dibungkus dengan warna Islam. Sebagian besar, untuk tidak mengatakan semua, gagasan-gagasan pembaruan yang ditawarkan tokohtokoh reformis dapat ditemukan korelasinya dalam tradisi intelektual yang berkembang di Barat.

g) Postradisionalis

Ketika wacana post tradisionalisme Islam (selanjutnya disebut postra) dimunculkan dalam belantika pemikiran Islam di Indonesia, dapat diduga akan 
memunculkan berbagai tanggapan, mulai dari yang apresiatif, biasa-biasa saja, sampai yang sinis. Apresiatif karena wacana itu dianggap dapat menggairahkan kembali dinamika pemikiran Islam di Indonesia yang diakui atau tidak, seolah "berjalan di tempat", tanpa perkembangan berarti. Biasa-biasa saja karena postra dianggap belum mapan basis epistimologisnya, bahkan tidak ada bedanya dengan arus pemikiran yang lain; dan sinis karena wacana ini dianggap sebagai kelatahan anak-anak muda NU untuk mempertegas identitasnya, bahkan dilihat sebagai "primordialisme baru" yang dibungkus dengan teori-teori yang canggih. Munculnya berbagai reaksi itu merupakan hal wajar dan tidak perlu diperdebatkan. Meski demikian-ini yang agak memprihatinkan-bila wacana postra semata-mata dianggap untuk mempertegas identitas kelompok, apalagi sebagai kelatahan, hal ini sebenarnya agak keterlaluan, meski anggapan demikian juga tidak dapat dianggap salah sama sekali.

Ada beberapa alasan yang mungkin dapat dijadikan argumen untuk membenarkan hal ini. Pertama, wacana postra lebih banyak disuarakan oleh komunitas yang sebagian besar afiliasi kulturalnya adalah Nahdlatul Ulama (NU). lembaga swadaya masyarakat (LSM) yang mempunyai perhatian terhadap perkembangan pemikiran dan menyuarakan tema postra, sebagian besar juga LSM yang afiliasi kulturalnya ke NU, meski juga harus diakui, banyak aktivis Islam liberal yang afiliasi kulturalnya juga NU.

Kedua, kata "tradisionalisme" telah menjadi cap yang menghunjam kuat sebagai identitas "orang NU". Karena itu, ketika muncul kata "postra" maka orang akan dengan mudah mengatakan bahwa "itu milik NU". Ketiga, munculnya wacana postra beriringan dengan semangat "Islam liberal" yang sedang menjadi gairah intelektualisme Islam belakangan ini dengan berbagai aktivitas pendukungnya. Dalam suasana demikian, postra mengesankan seolah ingin membedakan dengan Islam liberal, baik pada tingkat epistemologis maupun basis gerakannya.

Meski prihatin, tetapi itulah realitas kita. Kata "tradisional-modern" dan segala turunannya bukan saja telah menjadi kategori akademik, tetapi lebih dari itu, telah menjadi identitas kelompok yang di dalamnya diberi muatan "ideologi" tertentu. Arus demikian juga begitu kuat terasa ketika muncul arus neomodernisme dan Islam liberal di satu pihak dan postra di pihak lain. Jika yang pertama dianggap sebagai milik 
kalangan "modernis", yang kedua dianggap milik kalangan "tradisionalis" NU. Harus diakui, ini sebenarnya hal yang tidak sehat dalam konteks perkembangan pemikiran, karena pemikiran akan menjadi identitas kelompok.

Akibat dari paradigma yang demikian, maka Islam liberal menjadi kurang bisa menghargai tradisi lokal, kepercayaan lokal, adat istiadat dan seterusnya, karena dianggap bid'ah, inkretik, "tidak asli", kurang "Islami", bahkan penyimpangan dari Islam itu sendiri. Konsep ini jelas sekali tergambar dalam pikiran liberalis Islam (via Kurzman) ketika menguraikan rentetan kelahiran Islam liberal. Menurut pandangan Kurzman, sejarah panjang dalam Islam diwarnai tiga tradisi.

Tradisi pertama disebut "Islam adat" (customary Islam) yang ditandai pencampuradukan antara "tradisi lokal" (little tradition) dengan tradisi besar (great tradition) yang diandaikan sebagai "Islam yang asli" dan "Islam yang murni". Islam yang sudah bercampur dengan berbagai tradisi lokal dianggap sebagai Islam yang penuh bid'ah dan khurafat.

Atas dasar itu muncul arus tradisi kedua yang disebut "Islam revivalis" (revivalist Islam) yang bisa mengambil bentuk pada fundamentalisme dan wahabisme. Tradisi ini berupaya melakukan purifikasi (pemurnian) terhadap Islam yang bercampur tradisi lokal yang dianggap tidak Islami dan sebagai penyimpangan terhadap doktrin Islam "yang murni" dengan jargon "kembali kepada Al Quran dan hadis".

h) Modernis

Kata modern, modernisme, modernisasi, modernitas, dan beberapa istilah yang terkait dengannya, selalu dipakai orang dalam ungkapan sehari-hari. Karena perubahan makna yang terdapat di dalamnya, istilah-istilah ini seringkali memiliki makna yang kabur. Modern adalah sebuah istilah korelatif, yang mencakup makna baru lawan dari kuno, innovative sebagai lawan tradisional. Meskipun demikian, apa yang disebut modern pada suatu waktu dan tempat, dalam kaitannya dengan budaya, tidak akan memiliki arti yang sama baik pada masa yang akan datang atau dalam konteks yang lain.

Para peneliti agama, terutama, yang tertarik pada contoh-contoh budaya menurut sebuah kerangka jangka panjang, tidak harus lupa meletakkan pada persepsi perubahan perspektif dari apa yang disebut baru dan kuno. Karena penilaian tentang 
apa yang disebut modern adalah persoalan perspektif dari orang yang melihat, fenomena yang kelihatannya sama bisa jadi sangat berbeda tergantung pada konteks yang berbeda. Oleh karena itu, contoh karya arsitektur modern pada pertengahan abad ke-20 sekarang sudah terlihat kuno. Dalam bidang intelektual, modernisme Islam muncul karena tantangan perkembangan yang dihadapi oleh umat. Dalam abad ke-19 dan awal abad ke-20 tantangan politik yang dihadapi oleh umat Islam bagaimana membebaskan diri dari penjajahan Barat, tantangan kultural adalah masuknya nilai-nilai baru akibat dari kemajuan ilmu pengetahuan modern Barat, tantangan sosial-ekonomi adalah bagaimana mengentaskan kebodohan dan kemiskinan umat, dan tantangan keagamaan adalah bagaimana meningkatkan wawasan pengetahuan agama serta mendorong umat untuk bisa memahami ajaran agama secara mandiri.

Bagi muslim modernis, Islam memberikan dasar bagi semua aspek kehidupan manusia di dunia, baik pribadi maupun masyarakat, dan yang dipandang selalu sesuai dengan semangat perkembangan. Oleh karena itu, bagi kaum modernis tugas setiap muslim adalah mengimplementasikan semua aspek ajaran Islam dalam kehidupan nyata. Dasar pandangan ini dibentuk oleh satu keyakinan bahwa Islam memiliki watak ajaran yang universal. Universalitas ajaran Islam ini dilihat dari sapek isi mencakup semua dasar norma bagi semua aspek kehidupan, baik yang berkaitan dengan persoalan ritual maupun sosial, dari aspek waktu, Islam berlaku sepanjang masa, dilihat dari aspek pemeluk, Islam berlaku untuk semua umat manusia tanpa memandang batasan etnik maupun geografis.

Di antara ciri dari gerakan Islam modern adalah menghargai rasionalitas dan nilai demokratis. Semua anggota memiliki hak yang sama dan semua tingkat kepemimpinan dipilih tidak diangkat. Tidak ada perbedaan antara warga biasa dan ulama menyangkut hak dan kewajiban organisasi. Gerakan ini di Indonesia memiliki pengaruh kuat di kalangan kelas menengah kota, mulai dari pengrajin, pedagang, seniman sampai para professional. Sebagai sebuah fenomena kota, di antara karakteristik gerakan ini adalah "melek huruf", yang pada akhirnya ciri ini menuntut adanya pendidikan. Sehingga pendidikan merupakan program yang paling utama. 
Secara umum, orientasi ideologi keagamaan modernisme Islam ditandai oleh wawasan keagamaan yang menyatakan bahwa Islam merupakan nilai ajaran yang memberikan dasar bagi semua aspek kehidupan dan karenanya harus diamalkan dalam kehidupan sehari-hari. Bagi mereka, pengamalan ini tidak hanya terbatas pada persoalan ritual-ubudiyah, tetapi juga meliputi semua aspek kehidupan social kemasyarakatan. Dikotomi di atas sering kita kelompokkan dalam dua organisasi besar yaitu Islam NU dan Islam Muhammadiyyah. NU sering dilihat sebagai representasi kelompok tradisionalis, sementara Muhammadiyyah sebagai representasi kelompok modernis. Namun dikotomi ini kemudian dianggap tidak layak lagi, karena dalam perkembangan selanjutnya, NU bersifat lebih terbuka terhadap modernitas. Bahkan dalam sebuah penelitian yang dilakukan oleh Arbiyah Lubis, ditemukan bahwa Muhammadiyyah termasuk dalam kelompok tradisionalis modernis. Menurutnya, Muhammadiyyah tampil sebagai modernis hanya dalam dunia pendidikan, dan dalam memahami teks al Qur'an dan Hadith sebagai sumber ijtihad, Muhammadiyyah berada dalam kelompok tradisonalis.

\section{Hubungan Islam dengan Peradaban Barat Modern}

Hubungan Islam dengan Barat dalam sejarah panjangnya diwarnai dengan fenomena kerjasama dan konflik. Kerjasama Islam dan Barat paling tidak ditandai dengan proses modernisasi dunia Islam yang sedikit banyak telah merubah wajah tradisional Islam menjadi lebih adaptatif terhadap modernitas. Akan tetapi sejak abad ke-19, gema yang menonjol dalam relasi antara Islam dan Barat adalah konflik. Ketimbang memunculkan kemitraan, relasi Islam dan Barat menggambarkan dominasisubordinasi.

Pasang surut hubungan Islam dan Barat adalah fenomena sejarah yang perlu diletakkan dalam kerangka kajian kritis historis untuk mencari sebab-sebab pasang surut hubungan itu dan secepatnya dicari solusi yang tepat untuk membangun hubungan tanpa dominasi dan konflik di masa-masa mendatang. Barat selama ini dicurigai sebagai pihak yang telah memaksakan agenda-agenda "pembaratan" di dunia Islam. Dampak yang ditimbulkan adalah semakin terpinggirkannya peran ekonomi, politik, sosial dan budaya Islam dalam panggung sejarah peradaban dunia. 
Tidak hanya itu, Islam semakin tersudut dengan berbagai cap yang dilontarkan Barat terhadap Islam, mulai dari cap fundamentalis sampai teroris. Tentunya berbagai cap itu terselubung kepentingan tingkat tinggi (high interest) untuk membuat semakin terpojoknya Islam sehingga mudah untuk dijinakkan lagi-lagi demi kepentingan globalnya.

\section{KESIMPULAN}

Dari uraian yang terdapat dalam makalah ini dapat diambil kesimpulan sebagai berikut:

a) Perkembangan pemikiran Islam kontemporer yang luar biasa saat ini, sesungguhnya, dapat diklasifikasikan dalam 5 model kecenderungan yakni fundamentalis, tradisionalis, reformis, postradisionalis dan moderinis.

b) Pengertian model pemikiran Islam kontemporer yakni: Pertama, fundamentalis yaitu model pemikiran yang sepenuhnya percaya pada doktrin Islam sebagai satusatunya alternatif bagi kebangkitan Islam dan manusia. Kedua, tradisionalis (salaf) yaitu model pemikiran yang berusaha berpegang pada tradisi-tradisi yang telah mapan. Bagi mereka, segala persoalan umat telah diselesaikan secara tuntas oleh para ulama terdahulu. Ketiga, reformis yaitu model pemikiran yang berusaha merekonstruksi ulang warisan budaya Islam dengan cara memberi tafsiran baru. Keempat, postradisionalis yaitu model pemikiran yang berusaha mendekonstruksi warisa Islam berdasarkan standar modern. Kelima, moderinis yaitu model pemikiran yang hanya mengakui sifat rasional-ilmiah dan menolak kecenderungan mistik. Menurutnya, tradisi masa lalu sudah tidak relevan, sehingga harus ditinggalkan.

c) Pasang surut hubungan Islam dan Barat adalah fenomena sejarah. Barat selama ini dicurigai sebagai pihak yang telah memaksakan agenda-agenda "pembaratan" di dunia Islam. Tidak hanya itu, Islam semakin tersudut dengan berbagai cap yang dilontarkan Barat terhadap Islam, mulai dari cap fundamentalis sampai teroris. Tentunya berbagai cap itu terselubung kepentingan tingkat tinggi (high interest) untuk membuat semakin terpojoknya Islam. 


\section{DAFTAR PUSTAKA}

Abaza, Mona. "The Discourse on Islamic Fundamentalism in the Middle East and Southeast Asia: A Critical Perspective," Sojourn 6 (1991): 203-239.

Abdel Salam Sidahmed dan Anoushiravan Ehteshami (eds). Islamic Fundamentalism. Boulder, Colorado: Westview Press Inc., 1996.

Ahady, Anwar-ul-Haq. "The Decline of Islamic Fundamentalism," Journal of Asian and African Studies XXVII, 3-4 (1992): 231.

Ayubi, Nazih. Political Islam: Religion and Politics in the Arab World. London and New York: Routledge, 1991.

Binder, Leonard. Islamic Liberalism. Chicago: The University of Chicago Press, 1988.

Choueiri, Youssef M. Islamic Fundamentalism. Boston, Massachusets: Twayne Publishers, 1990.

Dekmejian, R. Hrair. "Islamic Revival: Catalysts, Categories, and Consequences." Dalam The Politics of Islamic Revivalism: Diversity and Unity, ed. Shireen T. Hunter. 3-19. Bloomington and Indianapolis: Indiana University Press, 1988.

Eickelman, Dale F. dan James Piscatori. Muslim Politics. Princeton, New Jersey: Princeton University Press, 1996.

Huff, Peter. "The Challenge of Fundamentalism for Interreligious Dialogue," Cross Current (Spring-Summer, 2002). http://www.findarticles.com/cf_0/m2096/2000_SpringSummer/63300895/print.jhtml

Ibrahim, Saad Eddin. "Anatomy of Egypt's Militant Islamic Group: Methodological Note and Preliminary Findings." International Journal of Middle East Studies 12, 4 (1980): 423-453.

Jainuri, Achmad. Orientasi Ideologi Gerakan Islam. Surabaya: LPAM, 2004.

Rahman, Fazlur. "Roots of Islamic Neo-Fundamentalism." Dalam Change in the Muslim World, ed. Philip H Stoddard, David C. Cuthell and Margaret V. Sullivan (Syracuse: Syracuse University Press, 1981.

Rahman, Fazlur. Islam. Second Edition. Chicago: The University of Chicago Press,1979.

Roy, Olivier. The Failure of Political Islam. Trans. Carol Volk. Cambridge, Massachusetts: Harvard University Press, 1994.

Shepard, William. "Fundamentalism Christian and Islamic," Religion 17 (11987): 355-378.

Shepard, William. "What is 'Islamic Fundamentalism'?," Studies in Religion 17, 1 (1988): 525.

Sihbudi, Riza, et.al. Islam dan Radikalisme di Indonesia. Jakarta: LIPI Press, 2005.

Sivan, Emmanuel. Radical Islam: Medieval Theology and Modern Politics. Enlarged Edition. New Haven and London: Yale University Press, 1985.

Voll, John Obert. "Relations Among Islamist Groups," dalam Political Islam: Revolution, Radicalism, or Reform?. Ed. John L. Esposito. Boulder, Colorado: Lynne Rienner Publishers, Inc., 1997, 231-247.

Voll, John Obert. Islam Continuity and Change in the Modern World. Second Edition. Syracuse: Syracuse University Press, 1994. 